'The multiple lives of Billy Waters: dangerous theatricality and networked illustrations in nineteenth-century popular culture'

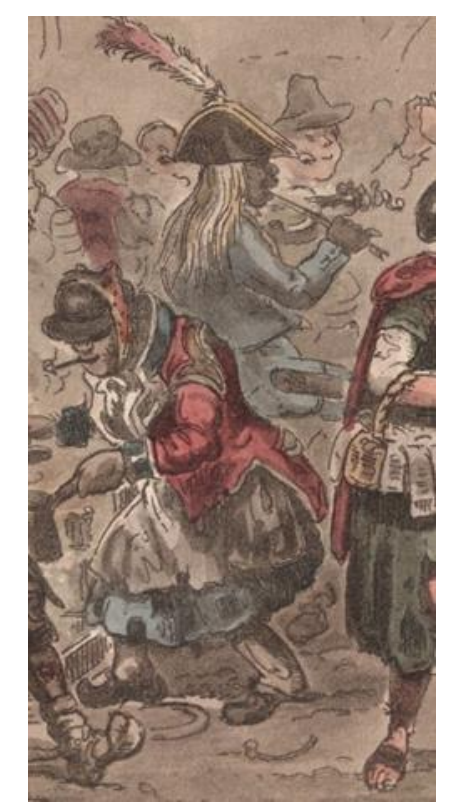

Figure 1: Billy Waters, (detail) in Robert and George Cruikshank, Tom and Jerry "Masquerading it" among the Cadgers in the "Back Slums" of the Holy Land, in Egan, Life in London. Author's Collection.

\title{
I: Introduction
}

Billy Waters (c. 1780 - 1823), the 'King of the Beggars', was a well-known figure in earlynineteenth-century popular culture, yet despite this he has received no sustained critical or cultural attention with no books or article devoted to him. ${ }^{1}$ Close attention to visual and textual depictions of Waters, however, offers the potential for developing a new model of 1820s and 1830s popular culture that shows - in more detail than the critical models currently available - how popular theatre connects with print and visual media. Waters was an AfricanAmerican ex-sailor, who lost a leg serving on the ship 'Ganymede' and so turned to busking in London to supplement his meagre pension. ${ }^{2}$ Waters' pitch was outside the Adelphi theatre on the Strand. His instantly recognisable visual characteristics make him a striking part of a 
key plate in Piers Egan and Robert and George Cruikshank's phenomenally popular serial text Life in London (1820-1). ${ }^{3}$ This illustration (Figure 1) shows Waters at the centre of a scene set in a tavern near Seven Dials, which Waters was said to frequent. ${ }^{4}$ Here Waters reproduces his street act indoors as part of the text's insistence upon the essential theatricality of London life, where everyone is performing. Waters adopted the distinctive costume (represented in the plate) of 'Cock'd hat adorned with various coloured feathers --- Sailor's jacket -- Canvas trowsers --- wooden leg' which - together with his fiddle-playing, his dancing, and his trademark song 'Kitty will you marry me' - made him a well-known figure on London's streetscape. ${ }^{5}$ As Charles Hindley (the nineteenth-century commentator who recorded most of the little we know about Waters' life) puts it, 'his ribbon-decked cocked hat and feathers, with the grin on his countenance, and sudden turn and kick out of his wooden limb, and other antics and efforts to please, excited much mirth and attention, and were well rewarded from the pockets of John Bull' ${ }^{6}$ The popular broadside-publisher James Catnach declared that '[e]very child in London knew [Waters]'; Douglas Jerrold asked 'who ever danced as he danced? Waters was a genius'. ${ }^{7}$ Waters' widest fame came, however, after he was immortalised in W. T. Moncrieff's hit 1821 stage version of Life in London. Inside the Adelphi, Mr Paolo played 'Billy Waters' on stage in a scene based on the Life in London plate; ${ }^{8}$ street performance, illustration and popular culture all intersected. This article analyses depictions of Billy Waters to propose a new model for ascertaining the relationship between ideological agency and popular cultural forms on stage and page.

Waters may have died in his mid-forties, but he lived multiple lives throughout the early nineteenth-century. As a figure in prints and books of London 'Cries', in Egan's bestselling work, in the numerous productions of Tom and Jerry, and in the ephemera produced in the wake of the craze for all things Life in London, he transcended his original context to reverberate through popular culture. In this he bears a striking resemblance to the 
fictional characters Mr Pickwick, Paul Pry, Corinthian Tom and Dusty Bob who also appeared on stage and on broadsides, as prints and as toby-jugs. ${ }^{9}$ Like these popular characters of the 1820 s and 1830 s, Billy Waters' celebrity rested on visual tropes and his multiple appearances demonstrate the close affiliations between different types of media, in an era before copyright reform. ${ }^{10}$ But because of his status as an instantly recognisable historical Londoner, Waters offers a unique way of approaching how ideas are conceived and formulated within vernacular culture. Despite the fact that scholars since Martin Meisel have explored how the development of tropes and stereotypes in nineteenth-century popular culture depends upon complex processes of transmission that combine theatrical, oral, visual, and printed media, we still lack an expansive-enough conceptual model for how precisely this works for illustration, particularly of popular characters from stage and page. ${ }^{11}$ Robert Darnton's influential book history model of the 'communication circuit' excluded illustrations and it also avoided explicit mention of interactions between print and theatre. Waters as a case study enables us to see that popular culture has its own kind of 'communication circuit', or perhaps more usefully communication network (as 'circuit' implies a closed system too neat for the complex interactions of popular culture) in which the mobility of images within popular culture works horizontally within a matrix rather than up and down cultural levels. This demonstrates the ways in which the visual culture of theatre is the key node in the network of Regency popular culture, influencing both visual and textual representation. Some critics have begun to recognise this: David Vincent has shown how the Paul Pry phenomenon (a stage character initially created by John Liston) reveals the early nineteenth-century fascination with, and interrogation of, issues of privacy and intrusion. Brian Maidment's compelling cultural history Dusty Bob interrogates the (fictional) Life in London characters Dusty Bob and African Sal, to show the transgressive and carnivalistic potential of their stage popularity as working-class and black Londoners respectively. But 
Billy Waters enables us to consider these issues from the starting point of an actual historical figure. Investigating Waters can help us to re-evaluate the cultural circulation of fictional figures such as Corinthian Tom, Mr. Pickwick, and John Bull in the context of scholarship on book history as well as on black British history.

This communication network meant that Waters' image circulated across popular culture, carrying associations with both theatricality and authenticity as it went. The historical fact of Waters' existence (for all that his 'reality' was visually and textually mediated) ${ }^{12}$ is used as a guarantee of certain kinds of authenticity for Moncrieff's play and for Egan's text in a different way to the fictional characters: a recognisable figure, Waters is an example of 'real life' in London. ${ }^{13}$ Of course, 'the real' was a contested area in nineteenth-century theatre, involving as it did debates about modes of mimicry, observation, and caricature. ${ }^{14}$ As Katherine Newey puts it, urban melodramas of this period claimed 'moral authority from verisimilitude': these kinds of productions, of which Moncrieff's play was one, claimed to present authentic London experiences live on stage not just to entertain, but to equip the audience to navigate the city and ensure that 'Virtue is triumphant' ${ }^{15}$ At the same time, Billy's notoriety as a performer drove the circulation of his image: he sang and danced in public for money, just like the actors of the Adelphi. The use and reuse of Waters' image allows us to track the ways in which representations of theatricality as a mode of urban life spread across different types of popular culture in a series of networked illustrations, and therefore to see vernacular culture's specific kind of communication network in action.

The historical Billy Waters, however, did not triumph. Ironically, his celebrity backfired and his theatrical alter-ego occluded his actual distressed circumstances. Waters was reported on his death to have entered St. Giles Workhouse because his depiction on stage as a mendacious cadger rather than a legitimate busker meant his income dried up, and he was said to have died cursing the play. ${ }^{16}$ It is one thing for fictional characters to take on a 
life of their own, but different issues are thrown up when a 'real' person becomes a character in ways beyond their control, especially when in the nineteenth-century that person was already disadvantaged by being poor, with a disability, and - in Waters' case - black. ${ }^{17}$ Theatricality is revealed as a dangerous metaphor for urban life: if all the world's a stage, then readers, audiences, and citizens are cushioned from the need to engage fully and seriously with urban problems (such as the rise of mendicity and day-labourers in a period when job security is not only an economic issue but also a defining factor in whether one was seen to possess citizenship). ${ }^{18}$ Largely forgotten and understudied, the multiple versions of Billy Waters need bringing out of the shadows into which he has slipped, because they offer us not only a deeper understanding of how this dangerous theatricality shielded consumers of Regency popular culture from the very realities which it purported to depict, but also a new insight into the way theatre functions within Regency popular culture.

\section{II: Regency Popular Culture and Darnton's Communication Circuit}

Billy Waters allows us to posit the influences, cross-fertilisations, and borrowings of tropes and stereotypes across popular cultural forms as a network which leads out from theatre though print and visual culture, and connects back round to the author via the characters like Waters upon whom such tropes and stereotypes settle. In an influential article on knowledge circulation, Robert Darnton used micro-history to consider how Enlightenment thinking worked on the ground. ${ }^{19}$ Darnton's proposal was a simple one: book history had become such 'a rich and varied field of study' that some order and distance was required for scholars to make any sense of what now looked 'less like a field than a tropical rain forest' ${ }^{20}$ Book history had reached a similar moment to nineteenth-century popular culture studies today: its very richness and interdisciplinarity was producing a torrent of interlocking ideas and approaches which Darnton felt were crying out for some kind of theorising. His solution was 
to 'propose a general model ... a communications circuit that runs from the author to the publisher ..., the printer, the shipper, the bookseller, and the reader. The reader completes the circuit because he influences the author both before and after the act of composition'. ${ }^{21}$ As Thomas R. Adams and Nicolas Barker have pointed out, Darnton's model in fact traces the history of communications rather than the history of books: the notion of a communication circuit works better for assessing the transmission of ideas through print culture than for book history per se. ${ }^{22}$ But this makes it a helpful concept for re-assessing the pan-media nature of Regency popular culture, and the ways in which ideas and tropes circulate within it.

Scholars have suggested modifications to Darnton's communication circuit ever since it was first proposed. Adams and Barker reorganised it around moments in a book's lifecycle, Innes M. Keighren applied it to geographic influences on book production, James Secord to the history of science, and digital humanists to digital publishing and digital tools. ${ }^{23}$ Even Darnton himself returned to it in later work, adding media such as broadsides, periodicals, and even gossip. ${ }^{24}$ Darnton's metaphor of upwards and downwards flow of current through the circuit points to one problem with his model. The rather flat idea of a circuit has significant limitations: Darnton's article recognised the growing research into popular culture, and declared that '[c]urrents [of cultural influence] flowed up as well as down, merging and blending as they went' ${ }^{25}$ Instead of a two-dimensional circuit, it makes more sense to view the interconnected currents of popular culture as making up a threedimensional network which connects stage, text, image, and ephemera in a complex web of influences: a matrix rather than a linear form.

As Darnton himself acknowledges, 'Models have a way of freezing human beings out of history', ${ }^{26}$ but visual representations of Waters offer a helpful way forward. Leigh Dilliard suggests that 'our consideration of illustration need not be confined by the physical boundaries of the book but should instead recognise a broader spectrum of parallel visual 
responses' ${ }^{27}$ She offers 'parallel illustration' as a term for 'images that exist on the physical periphery of the text but nonetheless inhabit a central space within the visual culture of the period' ${ }^{28}$ Dilliard groups these parallel illustrations into three categories: literary galleries, illustrations sold separately from the text as a collection of prints, and miscellaneous paintings and engravings. This idea could be taken further, however, particularly in the context of early-nineteenth century popular culture. Given the loose definition of 'illustration' in this period, ${ }^{29}$ the different forms of visual culture epitomised by the productions of the Life in London craze are also types of 'visual responses' which exist outside the 'boundaries of the book'. Crucially, Dilliard challenges any sense of hierarchy between original and works inspired by them. Her work builds usefully upon Meisel's 1983 study Realizations which established the interactions between stage plays, fiction, and literary paintings. ${ }^{30}$ As Patricia Smyth writes, 'the nineteenth-century represented a period of unprecedented exchange between the stage and the visual arts' ${ }^{31}$ But in applying these ideas to popular culture we might visualise the relationship between different kinds of popular media as a communication network. Plagiarism, in this context, is a term that is anachronistic culturally as well as legally. ${ }^{32}$ Instead, we have interlinked creative productions situated within a matrix of texts, genres, and influences. The communication network of Regency popular culture offers an alternative vision of culture to the one provided by an exclusive focus on the early nineteenth-century through the lens of romanticism's insistence on the power of original genius.

\section{III: Billy Waters and networked illustrations}

The multiple lives of Billy Waters show this communication network at work. The many manifestations and representations of Waters were driven by his visibility: the Strand was a main artery between Westminster and the City, and in the heart of a developing entertainment 
district. The street was Waters' stage, making literal the enduringly popular topos of theatrum mundi. Images of Waters appear in many diverse forms, but they overwhelmingly emphasise his theatricality, often in tension with an insistence on authenticity. First articulated as a specific term by Thomas Carlyle in 1837 for a set of ideas which had been circulating for centuries, theatricality has no clear definition, now or in the 1820 s and 1830s; however, Tracy C. Davis and Thomas Postlewait define theatricality loosely as relating to 'both the world of the theatre and the world as theatre'. ${ }^{33}$ Indeed, ' $[\mathrm{b}] \mathrm{y}$ the beginning of the nineteenthcentury, the idea of the stage's commensurability with theatricality in the social realm was well established' ${ }^{34}$ Davis goes further: theatricality in the early-nineteenth century, she suggests, is (unlike more modern notions of performativity) defined by the reactions of the spectator. When the spectator is in a position of critical distance from the observed show, instead of feeling absorbed sympathy, this creates a sense of theatricality. ${ }^{35}$

Waters' theatricality, therefore, lies in the ways in which he is represented and viewed. Before he was ever turned into a stage character Waters was an urban show, his act pre-dating the Jim Crow craze of a few years later. ${ }^{36}$ This made him a particularly appropriate figure to personify the Life in London craze, given that Egan's vision of London was of one giant spectacle in which every citizen played their part. ${ }^{37}$ In emphasising Waters' theatricality as part of a general feature of modern urban life (in the tradition of Hogarth's London scenes), most representations of him distance the viewer from any need to engage with his physical, embodied existence and turn him into yet another manifestation of popular culture tropes in ways which complicate distinctions between 'real' citizens with bodies and fictional characters as represented on stage or page. ${ }^{38}$

Before his depiction by Cruikshank in Life in London, or on stage at the Adelphi, Waters was already considered a figure worth memorialising. One of the earliest images of him is an oil painting by David Wilkie (Figure 2). This portrait has a quiet, grave dignity 
about it: Waters stands with his wooden leg prominent, wearing the red waistcoat which figured in later images, but without the extravagant cocked hat and fiddle which became such features of his role as a performer. He gives the viewer a wary yet direct look, biting his lip as if uncertain, though his stance is tall and open. Painted during or after the Napoleonic wars, this is Waters as noble veteran. Once peace was safely established, however, the fascination with so-called 'Cries of London' (or the dress and songs and habits of street sellers and street performers in the metropolis) meant that Waters' celebrity shifted firmly in the direction of popular culture and the signature components of Waters the performer took on a kind of brand recognition. He features as the first image in Thomas Busby's Costumes of the Lower Orders of London, Painted and Engraved from Nature (London: 1819), which was popular enough to run to a second edition in $1820 .{ }^{39}$ Out of twenty-two images in the book, Waters is one of only three named characters; the interest must be as much in Waters as a specific metropolitan spectacle as it is in him as a generic example of lower-class street culture. The key elements of costume later specified in Moncrieff's stage directions are all present: feathered hat, sailor's jacket, canvas trousers and wooden leg raised as if dancing to his own fiddle music. Images from the book were re-issued as prints (Figure 3), and so extended Waters' circulation. Note that here his wooden leg has switched from right to left: this could be a symptom of the engraving process, but images of Waters frequently shift the position of his wooden limb. ${ }^{40}$ The emphasis seems to be more on reproducing a key element of his act and aestheticizing poverty, rather than ensuring the images reproduce accurately his real physical body. Waters' representation here is similar to that of other lower-class black Londoners in the 'Cries' genre, such as Charles M'Gee and Joseph Johnson (or Black Joe). Both of these men were depicted in John Thomas Smith's Vagabondiana (London: 1817) as representatives of London's sizable black population, estimated at around 15-20,000, most of whom were free. ${ }^{41}$ Gretchen Gerzina argues that despite this local population, much of 
nineteenth-century understanding of 'blackness' was based upon plays, exhibitions, and other forms of spectacle; ${ }^{42}$ the 'Cries' genre contributed to this trend in its spectacularisation of the urban poor in general, including impoverished black Londoners in particular.

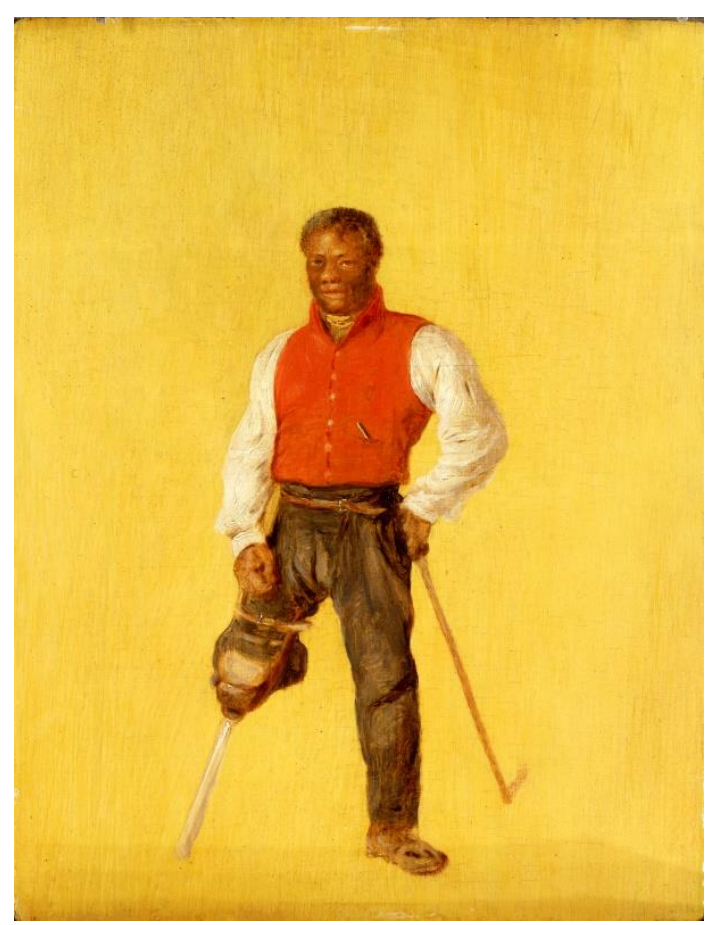

Figure 2: Billy Waters. David Wilkie. c. 1815. Oil on panel.

National Maritime Museum, London.

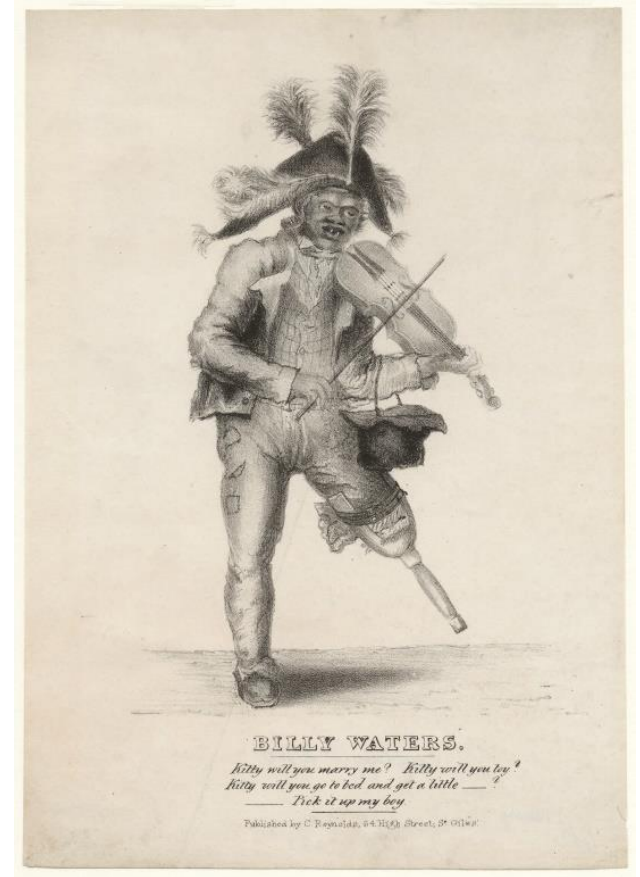

Figure 3: Billy Waters. Print after Thomas Busby. (C) National Portrait Gallery. 
In the years preceding Waters' appearance as a stage character, his image is already the site of tension between theatricality and authenticity. The second half of the title to Busby's book of engravings promotes the authenticity of the images inside, a point also emphasised in Busby's introduction. On one level, the 'Lower Orders of London' are intended as authentic representations of London street life. As I have argued elsewhere, authenticity 'was a concept ambiguously deployed in a literary culture where popular characters could be lifted from one context into another with no legal redress' ${ }^{43}$ However, authenticity also carried the meaning in the period of verisimilitude, of being 'true to life'. ${ }^{44}$ Of course, even this authenticity is filtered through the lens of theatricality: posed like theatrical prints and rendered picturesque, these street poor are there to be looked at, and there to assert the metropolis as a place of spectacle where every public act is also understood as a performance. As Marcus Wood points out, pity can turn exploitative when it asks the spectator to dwell on the sufferer's body as their own 'aesthetic property'. ${ }^{45}$ Waters is primarily differentiated from the implied reader or viewer by class here; in other examples he is differentiated by race. When George Cruikshank came to produce a caricature of the AntiSlavery movement in The New Union Club (1819), Waters is evidently well-known enough to take centre stage (Figure 4). In this satirical and racist print, published in the years before the 1833 Slavery Abolition Act, Cruikshank depicts the white Abolitionists as utterly out of their depth during a dinner with their black counterparts, which has descended into licentious chaos. Over it all, a grinning and grotesque Waters is shown performing with his fiddle, playing his own part in driving the drunken disorder. ${ }^{46}$ In the bottom right-hand corner, a white version of Waters is pursued by a black man with an alarming expression; the print threatens anarchy and even potential cannibalism if slavery is abolished in the West Indies. ${ }^{47}$ Black people, claims the print, simply cannot be dignified - this is in stark contrast to the Wilkie portrait. Cruikshank used Waters' image again in an anti-naval caricature Landing the 
Treasures, Or, The Results of the Polar Expedition!! (1819). ${ }^{48}$ In both prints, it is Waters' status as a performer which makes his image a portable shorthand for carnivalesque pleasures as well as a site of contestation for racist thought. ${ }^{49}$ It also makes him public property. Visible on the streets, and with no legal redress available to him, Waters' theatricality means that his image can be taken from him and dropped into any context to suit an artist's requirements.

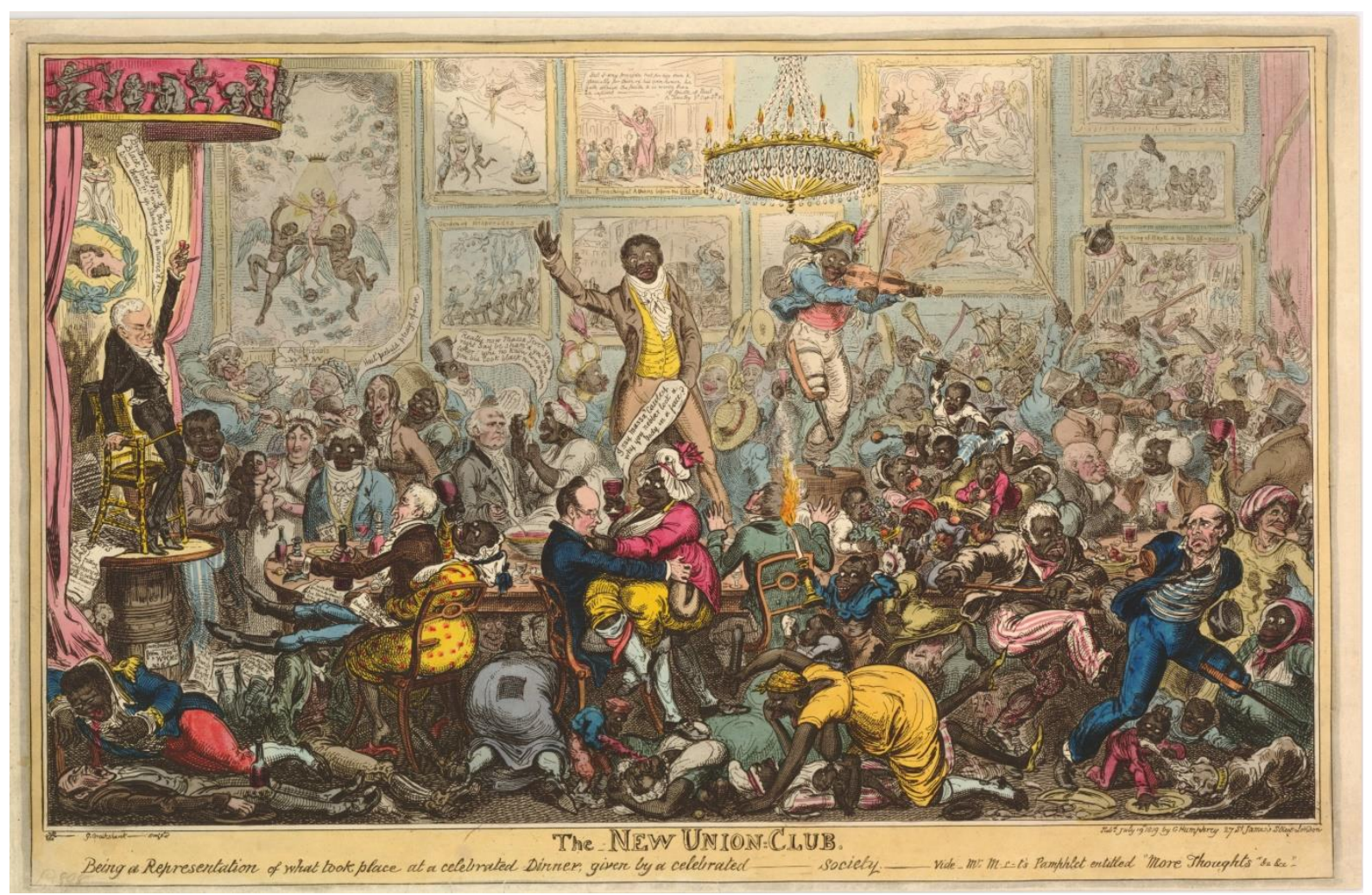

Figure 4: George Cruikshank. The New Union Club. 1819. (C) Trustees of the British Museum.

By the time Billy Waters appears in Robert and George Cruikshank's plate for Egan's serial Life in London, then, he brings with him associations of both urban authenticity and carnivalesque disorder. These made him a useful as well as a necessary inclusion. Life in London was a picaresque serial tale with elements of London travel and conduct guides, which entertained readers with scenes of metropolitan partying at society events and taverns alike. The episodic narrative follows friends Corinthian Tom and Bob Logic as they take Tom's inexperienced country cousin Jerry Hawthorn on sprees around London. The 
popularity of this text from the moment of its first appearance is difficult to overstate, and it says something for the importance of visual images in the development of the 'Life in London furore ${ }^{50}$ that a figure who is referred to only as ' $[\mathrm{t}]$ he black one-legged fiddler' in the text came to be associated so much with the Life in London phenomena as a whole. ${ }^{51}$ However insignificant Billy Waters is in Egan's letterpress, he is a striking part of the plate 'Tom and Jerry "Masquerading it" Among the Cadgers in the Back Slums of the Holy Land'52 (Figure 5), positioned as he is over the left shoulder of Peg the beggar girl who has caught Corinthian Tom's 'roving eye'. ${ }^{53} \mathrm{He}$ is at the centre of a variety of impoverished Londoners, black and white, all partying (and brawling) together. Waters may have been very visible on the Strand, but the plate takes us into the back alleys of St. Giles to his hidden life, where Waters was reputed to unwind at the Rose and Crown in Church Street. ${ }^{54}$ This pub was known by its dramatic sobriquet 'The Beggar's Opera', a reference to Gay's comic opera of the same name; even as Waters is presented as a visual sign of authenticity, this authenticity is already tied to performance.

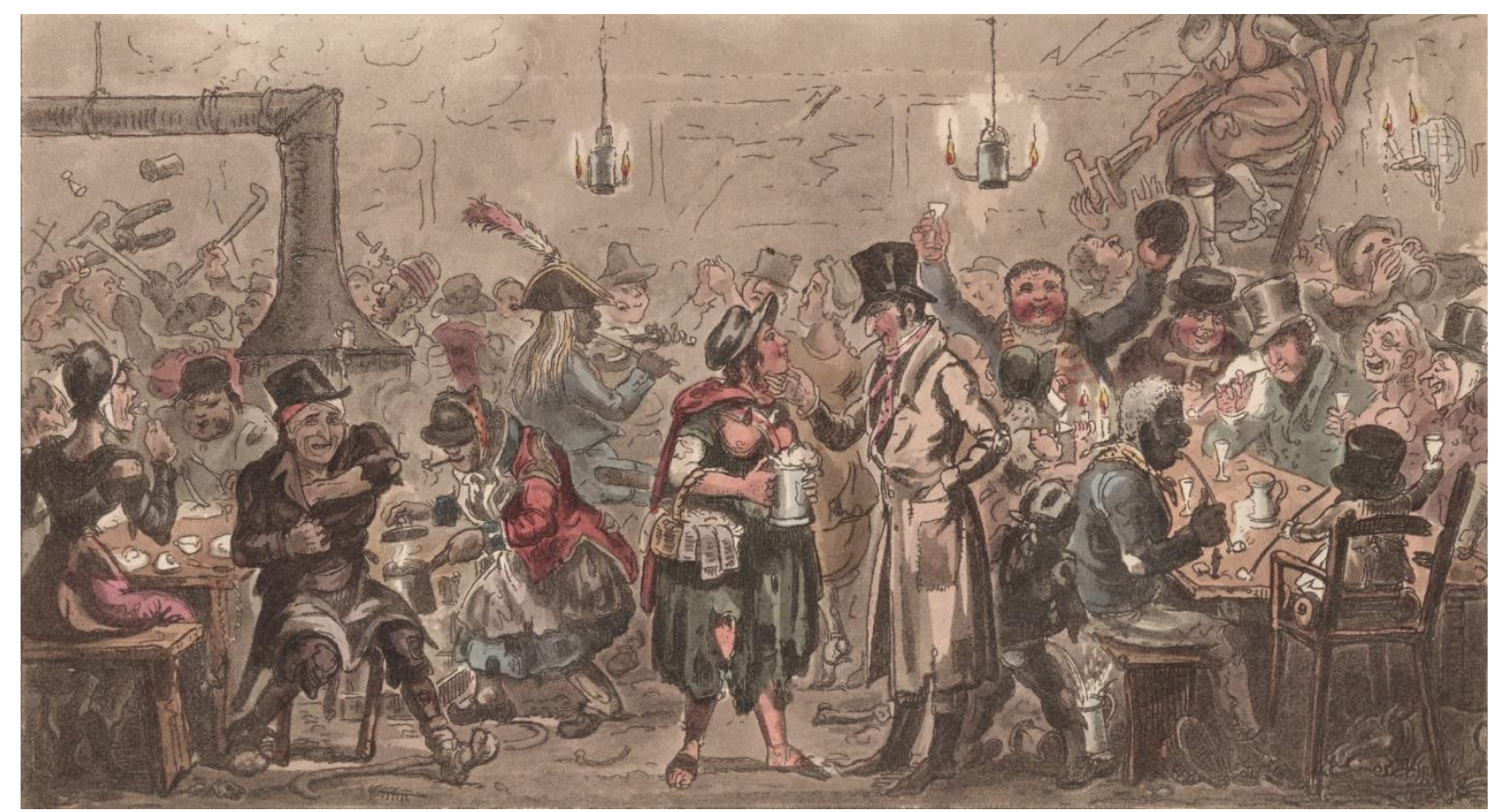

Figure 5: Robert and George Cruikshank. The Holy Land. Full plate. In Life in London (author's collection) 
For all that Waters' image carried with it connotations of authenticity, the Cruikshanks' plate was soon turned into unauthorised reproductions. James Catnach the successful publisher brought out a series of broadsides with cheap woodcut versions of the Cruikshanks' plates, and with verse summaries of Egan's plot. Catnach's Life in London... attempted in Cuts and Verse features a quieter version of the Holy Land plate (Figure 6). Billy is clearly visible with his hat, fiddle, and the strut of his wooden leg, particularly as the background of the tavern has been emptied out. Just as the original serial has been abridged into a series of short comic verses by the enterprising Catnach, so the scene has been simplified for the cruder woodcut image. The broadside is a large and elaborate sheet of twelve 'cuts'; strikingly of all the woodcuts copied from the original Cruikshank brothers' plates, it is this image of the Holy Land which is chosen as the largest and most prominent. Waters features in Catnach's broadsheet The Tears of London For the Death of Tom and Jerry, where key characters from the play mourn the closing of the play's run as they file past the Adelphi (Figure 7). Waters even got his own broadside from the Catnach press, 'The Death, Last Will, and Funeral of Black Billy', in which Waters' body passes the 'Beggars' Opera' in a similar coffin to Tom and Jerry's. Arguably as much as the fictional pairings of Tom and Jerry, and Dusty Bob and African Sal, Waters and the Life in London craze had become intertwined. By the time Egan produced his sequel Finish to Life in London (1829) it was almost inevitable that Robert Cruikshank's frontispiece included a small image of Billy, dancing (Figure 8). ${ }^{55}$ The image is entitled 'Folly'; Billy Waters is so divorced from the fact of his historical reality that he has been turned into an allegorical figure, and not a flattering one. The verse at the very bottom of the frontispiece links Billy specifically to the levelling effect of carnivalesque misrule: his advice to the reader is that 'Massa Death' will spare 'neither TOM, LOGIC, KATE, or one slave'. Billy represents his own folly, and the folly of the unwary reader or spectator who cannot see the theatricality of his performance. 
CUT VI. Beggars Opera---Tom, Jerry, \& Logick, among the Cadgers in the Holy Land.

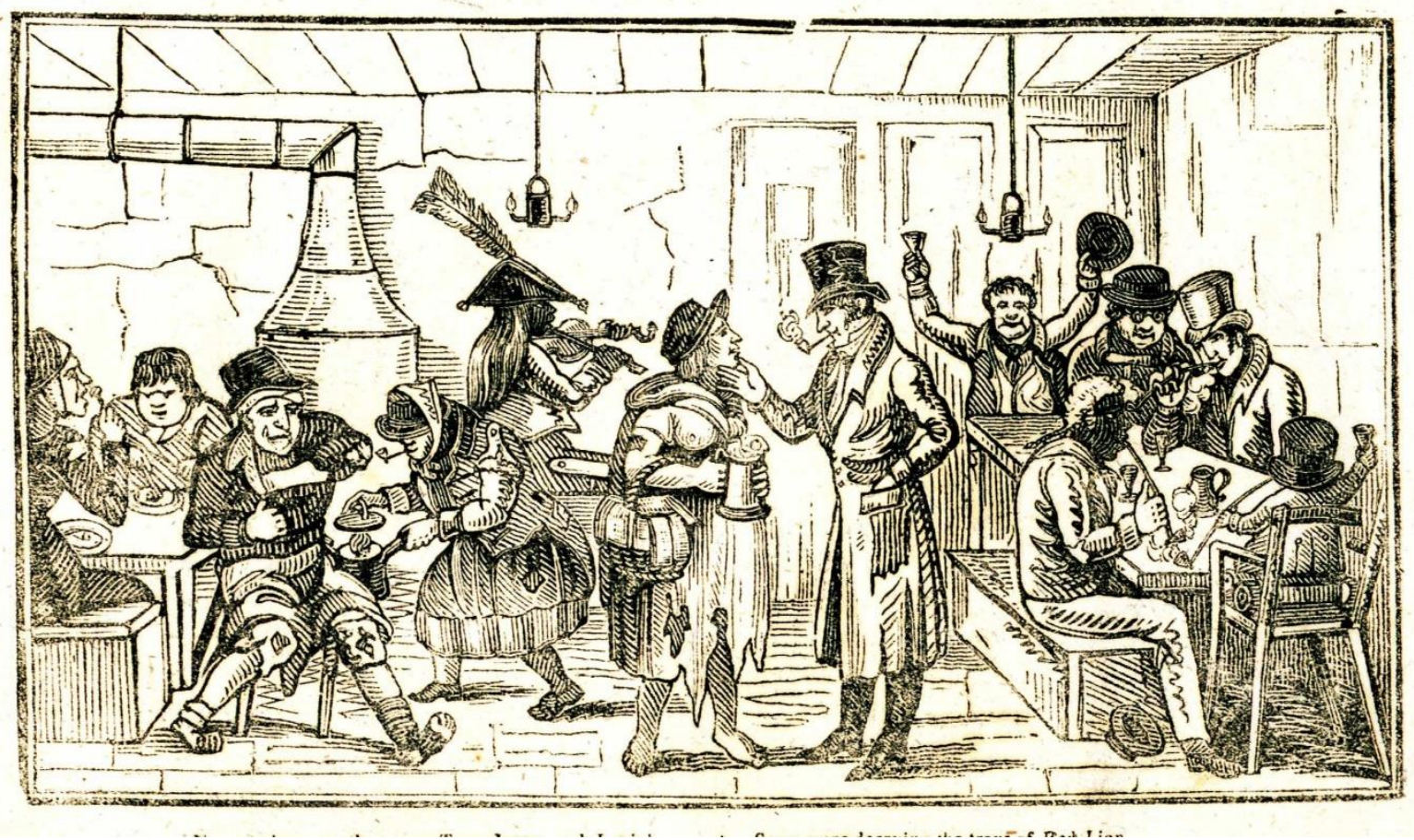

Figure 6: Part of a Catnach broadside, Life in London... attempted in Cuts and Verse. $5^{\text {th }}$ ed.

March 23, 1822. CBritish Library Board. General Reference Collection L.R.271.a.2. Item 11.

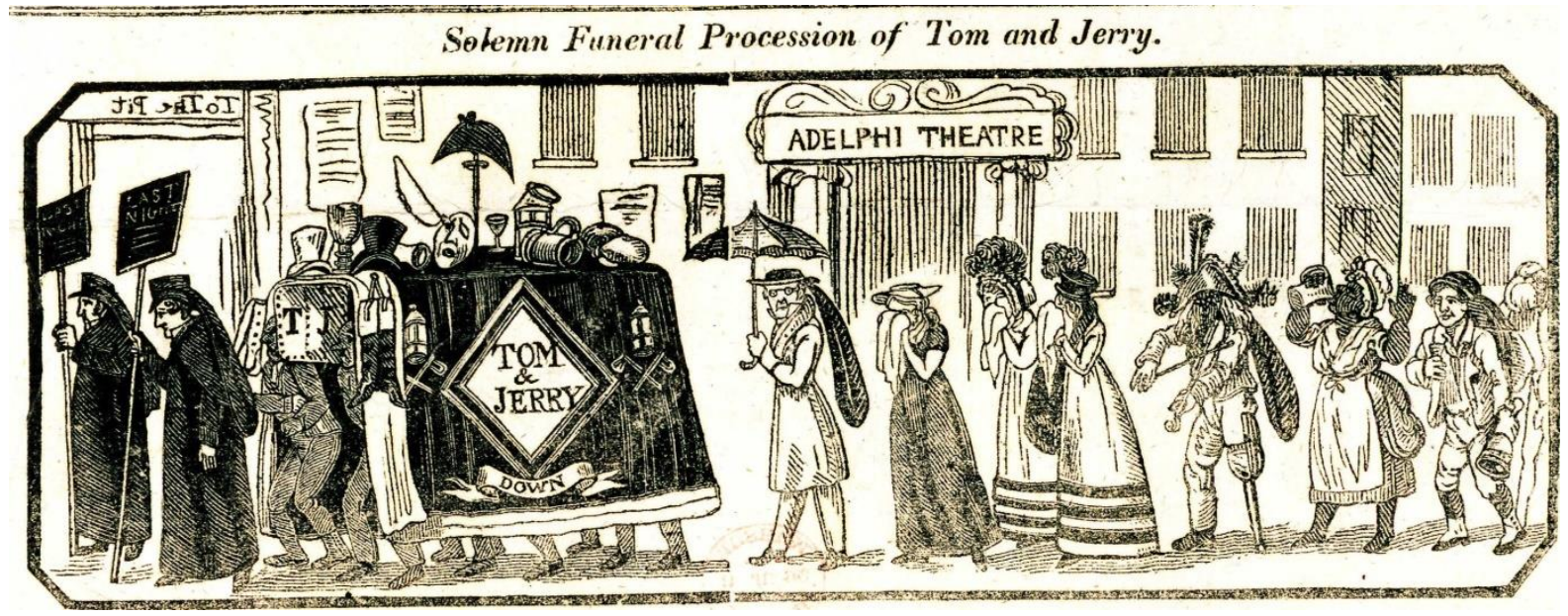

Figure 7: Part of a Catnach broadside, The Tears of London. $10^{\text {th }}$ ed. March 23, 1822.

(C)British Library Board. General Reference Collection L.R.271.a.2. Item 15. 


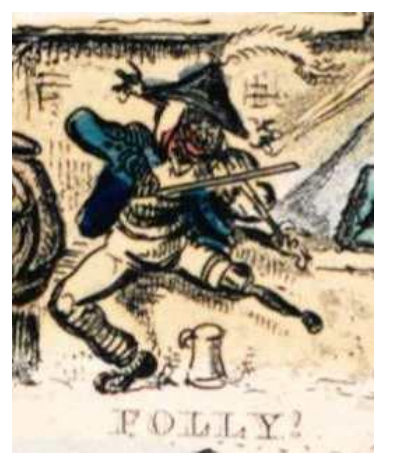

Figure 8: Frontispiece, Pierce Egan's Finish to Life in London (detail). Robert Cruikshank. CBritish Library Board. General Reference Collection C.70.g.15.

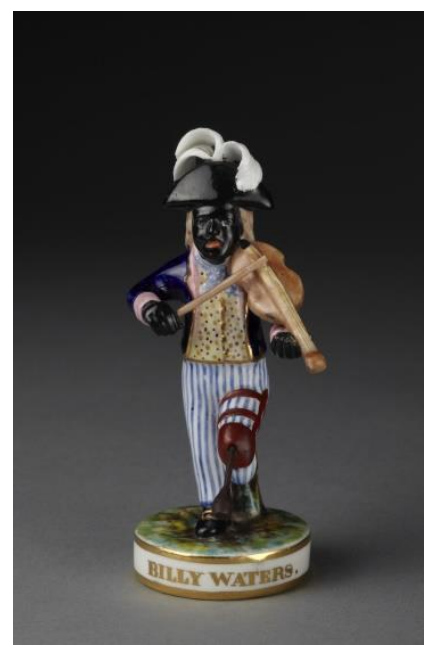

Figure 9: Derby ware figurine of Billy Waters. Edward Keys. 1862.

(C) Victoria and Albert Museum, London.

Prints of Billy Waters influenced illustrations, which inspired memorabilia, which led back to illustrations; the reuse of Billy's image did not stop there. Like many fictional characters from page and stage, including Pickwick, Paul Pry, and Dusty Bob, he made the shift into ephemera. As Egan himself notes, characters from Life in London adorned handkerchiefs, mantelpieces, and tea-tables:

[T] he plates, by ROBERT and GEORGE CRUIKSHANK, were considered so full of amusement, that they were transferred to a variety of Articles without loss of time. 
The Lady (...) was able to amuse her visitors with the adventures of TOM and JERRY on her highly-finished TEA-TRAY.(...) The Country Folks were delighted with the HANDKERCHIEF which displayed TOM getting the best of a Charley; and DUSTY BOB and BLACK SAL “all happiness!” (...) and the Connoisseur, with a smile of satisfaction on his countenance, contemplated his SCREEN, on which were displayed the motley groups of high and low characters continually on the move in the Metropolis. $^{56}$

Images of Waters circulated in exactly the same way. From 1821 onwards manufacturers brought out Derby and Staffordshire ware figurines of him, as others continued to profit from Waters' image: versions from the 1860 s attest to a continuing consumer demand (Figure 9). These ceramics, with their often crudely-done colouring, tended to emphasise Waters' blackness (although they were, on the whole, much more subtle and individuated than the racially caricatured figurines of black bandsmen popular from the 1760 s onwards).${ }^{57}$ Brighton Museum's Willett Collection of popular ceramics reveals that different versions of Billy Waters figurines were in circulation throughout the nineteenth-century, with varying degrees of quality. A c. 1825 Staffordshire figure in enamelled pearlware was based upon the Life in London illustration of Waters, while several cruder Staffordshire figurines were based on a print by Enoch Wood. ${ }^{58}$ A plaster statuette from 1821 by Robert Shout is clearly based upon Busby's 1819 print, and bears on its back the legend 'Pbld. Mar 1821 by R Shout \& Son Holborn, London', as if it was itself a piece of printed matter. Illustration and ceramics met from different parts of the network of popular images of Waters. ${ }^{59}$

Waters' notoriety at his death meant that he reappeared in the kinds of text which originally made him famous. Busby's Cries of London Drawn from Life (1823) and Hodgson's book for children The Cries of London (c. 1824) both feature Waters yet again, as 
his image reappears in the 'Cries' genre. ${ }^{60}$ In an 1822 etching (Figure 10) Waters is shown at the centre of a crowd of Londoners, entertaining them with his dancing and playing. The equestrian statue of Charles I positions us at Charing Cross, and the watching crowd are a realistically drawn cross-section of London society, from fashionables to street sellers. However, the small boy imitating Waters' dancing in the background points to the fact that Waters is not the only performer on stage here: every figure in the scene forms part of the urban spectacle, to be gazed at by the viewer, although Waters is the one being most obviously mocked and undermined. Waters is differentiated by his race in the title of the etching, but the colouring has rendered him little different to his audience. Unlike in the ceramics, Waters becomes just another Londoner rather than a representative of 'blackness'. Paradoxically, Waters represents 'real Life in London' precisely because he is a performer, as vernacular tropes pass from medium to medium and are complicated as they go. The communication network of Regency popular culture plays a crucial part in this process.

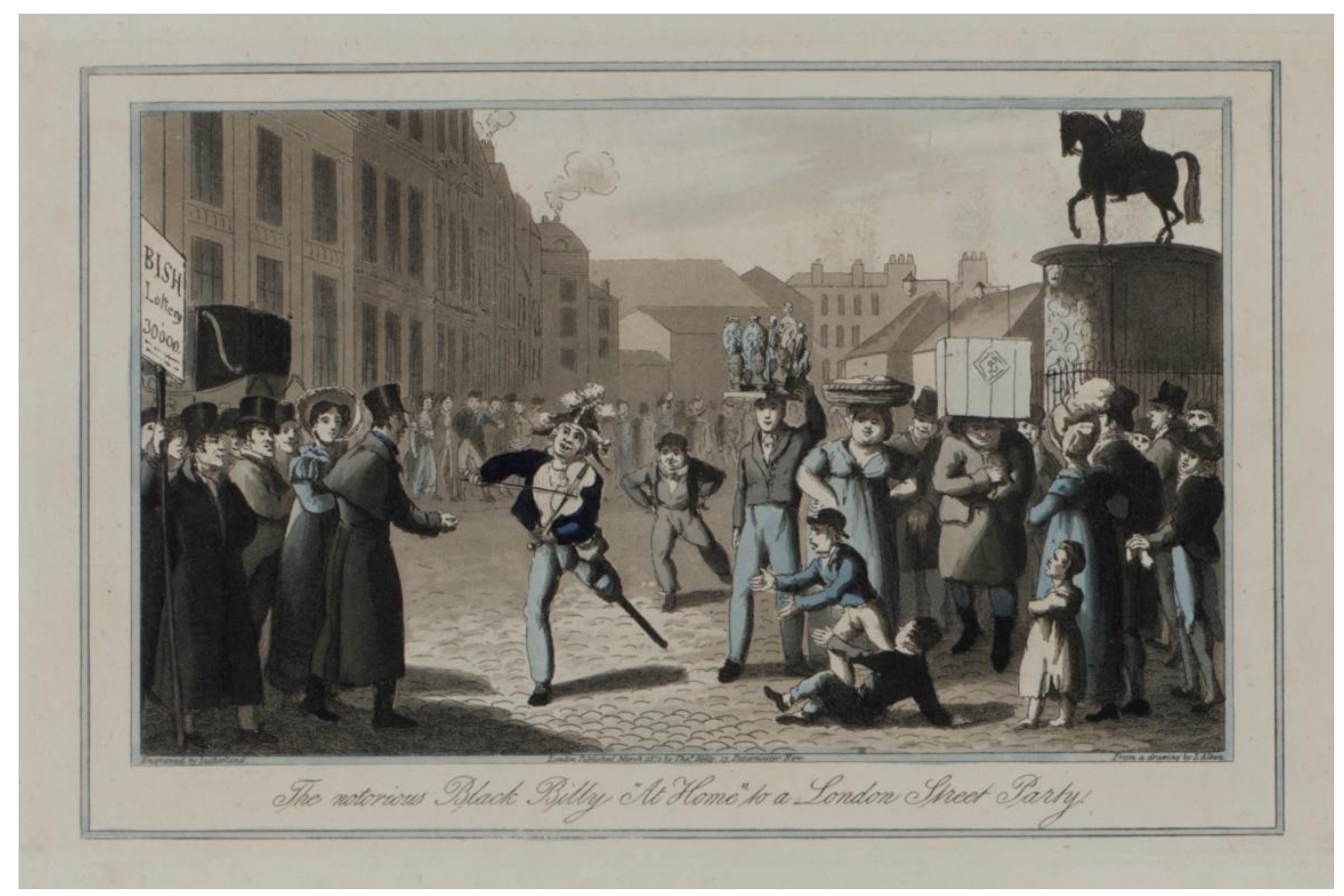

Figure 10: S. Alken. The notorious Black Billy 'At Home' to a London Street Party. 1823. National Maritime Museum, London. 


\section{IV: Billy Waters on the Adelphi Stage}

The tension between theatricality and authenticity moved easily across these interconnected images, and it is a key component of Moncrieff's representation of Billy Waters. Waters may have come to public notice as a performer outside the Adelphi, but he gained widest notoriety as a character in a play performed within it. Moncrieff's unauthorised Tom and Jerry: or, Life in London was the most famous and successful of the many theatrical adaptations of the text, and ran for over three hundred performances over two seasons 1821-23. ${ }^{61}$ Its continued availability in Dick's Standard Plays and French's acting edition secured its enduring appeal, and productions of Tom and Jerry were mounted up to the 1870s; Maidment notes that in 1821 and 1822 there were ten productions of Tom and Jerry in London and the surrounding area alone. ${ }^{62}$ Waters appeared in other stage versions of Life in London; frustrated by Moncrieff's success, Egan brought out his own stage version at Sadler's Wells, complete with pony races and a Mr. Hartland playing Billy Waters. ${ }^{63}$ This did not stop the adaptations coming thick and fast: versions of Billy Waters appeared on stage in Brighton, Edinburgh, New York, and Philadelphia, taking his image transatlantic. ${ }^{64}$ In both London and America, it was Moncrieff's adaptation which 'became the standard text' ${ }^{65}$ In this play, Waters' role as a performer is used in celebration of his fellow beggars, but also used against them.

Moncrieff advertised Tom and Jerry from the start as a production 'founded' on Egan's letterpress but closely faithful to its illustrative plates. The Adelphi production was overseen by Robert Cruikshank, and the sets drew upon the Cruikshank brothers' illustrations; ${ }^{66}$ indeed, Moncrieff's famous (although probably apocryphal) defence against a plagiarism charge levelled at him by an angry Egan was that ' $[I]$ wrote my piece from the inimitable plates - Cruikshank's plates - and boiled my kettle with your letterpress - that's

the plain fact'. ${ }^{67}$ Moncrieff's production specifically linked illustration to the visual culture of the theatre, as playbills proclaimed the production to be 'An animated Picture of every 
Species of Life in London'. ${ }^{68}$ Egan's own adaptation for Sadler's Wells made great play of the fact that it used the original creative team by having Egan's text and George Cruikshank's sets. For all adaptations, high value was placed on bringing the plates to life, and on using original actors across productions, in costumes that were the exact replicas of their engraved incarnations. As Philip Cox puts it, "[t]he centrality of the "illustration-tableau" in the adaptations of this period clearly indicates the importance the playwrights give to the visual elements of the original volumes'. ${ }^{69}$ This emphasis gave Waters much more prominence than he might otherwise have had, as Moncrieff turned a nameless figure in Egan's letterpress into a named role in the play with a key scene and a listing on the playbill.

Billy Water's image signified both authenticity and theatricality in Moncrieff's play. The promise of 'Billy Waters' on stage offered by the playbill was a marker of authenticity in two senses. It was a guarantee to the audience of an authentic adaptation of the original serial text; its genuineness as a product of the Life in London craze. ${ }^{70}$ But it also claimed the kind of authenticity that we have seen already associated with Waters' image. Billy Waters the character is deployed in an attempt to verify the play's depiction of real London life, which could be laid before the audience as a shared experience. The Cumberland edition of Moncrieff's Tom and Jerry takes great pains to list the costumes, with Billy Waters's specified as that found in the Cruikshank's illustration, but also on the real man outside the theatre doors. ${ }^{71}$ 'Billy' appears in Act 2 scene 3, set in the 'Back Slums in the Holy Land'. 72 As the scene opens, the stage directions tell us that the audience sees 'several well-known Characters discovered', with the capital ' $C$ ' alerting us to the fact that these are not just characters in a play, or from a serial tale, but also 'types' of urban poor from the London streets. ${ }^{73}$ After a song by these self-proclaimed 'Cadgers' on the joys of begging, the stage direction is 'Enter BILLY WATERS, dancing'. Billy's first appearance on stage is designed to replicate the audience's other encounters with his act or his image, as Billy dances his 
distinctive jig. This was so successful that audiences (and some critics) remained unsure if they were watching Waters playing himself on stage, or an actor. ${ }^{74}$

At the same time as being a figure of authenticity in the play, Billy is also a figure of theatricality. Billy's dancing entrance positions him as a performer, especially as it closely follows the Cadgers' opening song, a song which proclaims all begging to be one sustained performance for financial gain, '[f]or who but a slave would work,/When he like a prince might live?'. ${ }^{75}$ The reference to slavery here only hints at Waters' possible early life, as the script skates over uncomfortable realities (although given contemporary debates about the potential dangers of abolishing slavery in the West Indies, the portrait of an ambivalently attractive black beggar may have recalled this context to some audience-members). ${ }^{76}$ The idea of the deceitful beggar was of course not original to either Moncrieff or Egan. As Hepburn points out in his study of nineteenth-century broadside ballads, surviving ballads 'show considerable numbers of both unworthy and worthy beggars', with many references to cadging and descriptions of 'dodges employed by beggars to incite pity'. ${ }^{77}$ That such tropes had political significance is evident: the 1816 report of the House of Commons Select Committee into begging in London declared that '[a] Negro beggar retired to the West Indies with a fortune, it was supposed, of $£ 1500 \ldots$ Out of 400 beggars in St. Giles, 350 are capable of earning their living' ${ }^{78}$ This report led to the creation of the Society for the Suppression of Mendicity in $1817 .^{79}$ In Tom and Jerry, this trope becomes emblematic of the play and of London as a whole, with Billy as its embodiment.

Theatricality in this scene, but also in the play as a whole, is declared a mode of urban life, and it takes its cue from Billy. After a comic discussion about how successful they are at deceiving citizens into giving them money, the Cadgers break into another song: 
Then let us cadgers be, and take in all the flats we can,

Experience we know full well, my boys, it is that makes the man;

And for experience all should pay, that Billy will allow. ${ }^{80}$

The 'experience' of being cheated by Billy and his Cadgers is presented as a humorous and inevitable part of city life, and a worthwhile experience for the young and unwary. Deciphering the authentically needy from the practised actor, it is suggested, is something the modern citizen must learn. The play's male protagonists enter in the second half of the scene, observed by the female leads Sue and Kate (two other roles greatly expanded from Egan's original letterpress). All are 'disguised as Beggars' to fit into the tavern crowd:

Enter TOM, JERRY, and LOGIC_-disguised as Beggars, with Placards on their backsTOM'S “Burnt Out_lost my little all.”-JERRY'S “Deaf and Dumb.”- LOGIC'S "Thirteen Children." \&c.

Sue. Here they are-I know them in spite of their rags.

Tom. This, my dear Jerry, is a rich page in the book of life, which will save you many a pound, by exposing the imposition of street mendicity.-It almost staggers belief that hypocrisy is so successful, and that the fine feeling of the heart should become so blunted, as to laugh at the humanity of those who step forward to relieve them. ${ }^{81}$

Of course, echoing Egan's letterpress, Moncrieff's tongue is firmly in his cheek here; Tom and Jerry's disguises expose them as just as mendacious as the Cadgers. Indeed, it is only by acting the part of beggars that they can get the necessary experience for urban survival. Virtue will only triumph if it understands the essential theatricality of the city - and has a little help from those more knowing (for all the men's supposed worldliness, the women see through their disguises instantly, although the men never recognise the women). Street 
mendicity is simply street mendacity: the audience is sheltered from any need to worry about the Cadgers because it is assured that the poverty of all beggars is just one big act.

While allowing the poor agency, pleasure, and power on stage, then, the scene also undermines the position of marginalised citizens such as the historical Billy Waters. Billy enjoys significant status in the scene: promoted from a background (if eye-catching) figure in the original illustration, Moncrieff's Billy directs the action, interacts with Sue, and bullies the landlord of the tavern in the kind of English often reserved in nineteenth-century texts to denote racial difference: ${ }^{82}$

Jemmy. Gemman, have you ordered the peck and booze for the evening?

Sold. Suke. Aye, aye, I've taken care of that—shoulder of veal and garnish-Turkey and appendleges - Parmesan-Filberds - Port and Madery.

Billy. Dat dam goot, me like a de Madery-Landlord, here you give this bag of broken wittals, vot I had give me to-day, to some genteel dog vot pass your door: and make haste wid de supper, you curse devil you!

Billy. [...] (takes candle, and looks at supper). Vy, what him call dis?

Land. Why, the turkey and the pie, to be sure.

Billy. De turkey and de pie! I tink you said de turkey and de pie,- - what! de turkey without de sassinger! him shock—him wouldn't give pin for turkey without dem—me like a de Alderman in chain.

Land. I'm very sorry, Mr. Waters, but-

Billy. You sorry! I'm sorry for my supper, you damn dog. ${ }^{83}$

Hindley speculates that this dialogue - where Billy scorns the 'broken wittals' given to him by a well-meaning member of the public and berates the landlord for serving an inadequate supper in the manner of a spoilt 'Alderman' - was significant cause of the '[t]he fickle British 
public refus[ing] to be as liberal as they had been' to the historical and impoverished Billy Waters. ${ }^{84}$ Billy is full of vitality and agency, eventually ordering his companions to carry him off when the scene closes with the police threatening to break down the door. But he is also reduced to a racial and comic stereotype. His accent, marking him as an unmistakable 'other', and his dancing align him with the other popular working-class characters Dusty Bob and African Sal, who were known for their comic pas-de-deux. Jenna Gibbs points out that the presence of a black visitor to the Royal Academy in one of the original Life in London plates (Figure 11), participating in the spectacle of a society event in his white tie and tails, is evidence of a more nuanced approach to race in the text. ${ }^{85}$ But the small boy and the monocled gentleman staring at him as others are staring at the numerous portraits on the walls suggest that he is a less-than-usual addition to the Royal Academy crowd. Overall Moncrieff's and Egan's texts both have 'an essentialist reading of black characters', with no class or spatial mobility for Waters or indeed for any of the lower-class characters. ${ }^{86}$ As Hazel Waters puts it, 'theatrical fashion drew upon and re-presented underlying material realities' ${ }^{87}$ Despite them having to walk past Waters on their way to and from the theatre, 'Billy's' theatricality and the pan-media transference of this trope serves to protect consumers of popular culture from the uncomfortable realities of the urban poor, both black and white.

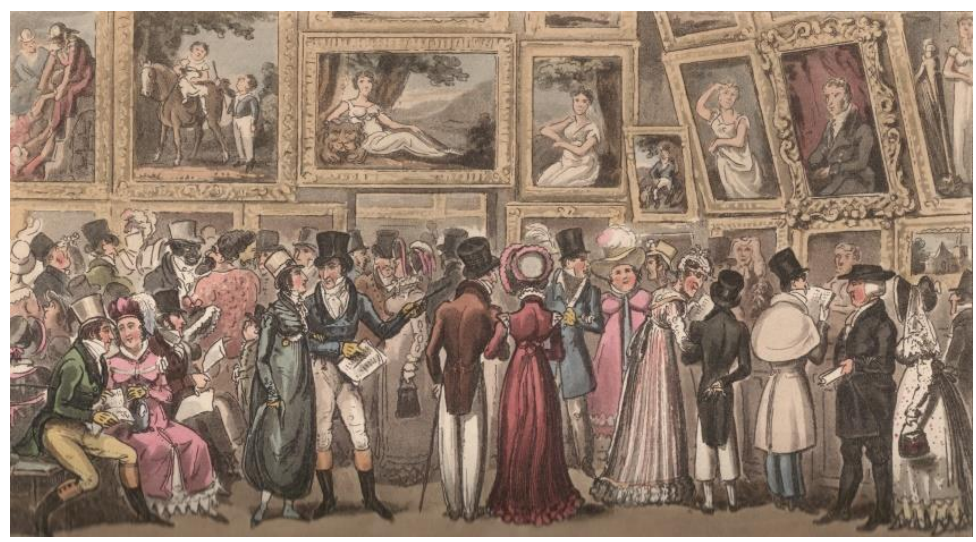

Figure 11: Robert and George Cruikshank. Tom and Jerry at the Exhibition of Pictures at the Royal Academy. In Life in London (author's collection) 


\section{V: Billy Waters and Dangerous Theatricality}

Billy Waters' street performances were the starting point for this network of representation, and this fact does provide him with a moment of historical agency. Just as the various media were reproducing and reimaging Waters, so it is entirely possible (if unknowable) that Waters in his turn played up those elements of his performance which had become most well-known. It certainly would have increased his notoriety, and may have prompted the numerous devotees of Tom and Jerry to make Waters' pitch a stop on their own tourist trail. However, the 1823 ballad 'Lines on Billy Waters' emphasised his powerlessness in the face of a fickle public and a famous play:

Mags came thick, this made him merry;

Fortune changes in a crack-

Folks they went t' see Tom and Jerry, And on Billy turned their back. ${ }^{88}$

As Hindley puts it, in what is something of a melodramatic conceit:

One notable effect of "Life in London," particularly in its dramatised form must be recorded. It broke the heart of poor Billy Waters, the one-legged musical negro, who died in St. Giles's workhouse, whispering with his ebbing breath, a mild anathema, which sounded very much like: "Cuss him, dam Tommy Jerry!"89

Billy clearly saw none of the revenue from Moncrieff's theatrical success; in this he is joined in complaint six years later by Egan himself:

We [the Author and Artist ] have been pirated, COPIED, traduced; but, unfortunately, not ENRICHED by our indefatigable exertions; therefore NOTORIETY must satisfy us, instead of the smiles of FORTUNE. Our efforts have given rise to numerous 
productions in the market of literature; yet we can assert, / with a degree of confidence hitherto unshaken, that none of our Imitators have dared to think for themselves during the / long period of seven years, neither have they shewn any originality upon the subject of LIFE IN LONDON. ${ }^{90}$

The footnotes in which Egan lists a sample of these unauthorised appropriations fill up most of these three pages, making the point visually that the imitations and derivative works crowd out the voices of the original contributors.

Rather than describing the various different uses of Billy Waters' image across the Life in London craze as plagiarisms, imitations, or derivative works, we might consider them as part of a network of popular illustrations. Moncrieff's play is both different from, and draws upon, Egan's letterpress and the Cruikshanks' plates. Not only does the Adelphi playbill claim for Moncrieff the title of 'Author', in place of Egan, but it cheekily announces that it will improve upon Egan's serialised version:

Tom and Jerry, it will be seen, have a moral Purpose and an Aim, and are not left on the Town, but conducted to a final Home. Sue and Kate are proved to be very different Characters from those they have been represented; and the Public will be glad to learn how their old Friend Logic was extricated from the disagreeable Situation, in which his original Godfathers left him. ${ }^{91}$

But the tension between theatricality and authenticity is already present in Egan's text, even if Moncrieff brings it out by enlarging Waters as a character. ${ }^{92}$ The 'scene' Jerry witnesses amongst the Cadgers in the Holy Land, and so by extension the plate which the reader sees, is described by Jerry as 'the climax' of everything he has 'witnessed' in London so far; ${ }^{93}$ the position of the plate and its accompanying description, as the last of the big set-piece scenes, adds weight to this statement. The Cadgers reinforce lots of things important to the whole 
text's interest in the meaning and extent of visual authenticity. The visit by Tom, Jerry and Logic to the Holy Land comes after their trips to the theatre and the masquerade, but Tom assures Jerry beforehand that even 'the Grand Carnival' is 'nothing to it, by comparison'. ${ }^{94}$ On one level, there is nothing authentic about the beggars whom the three friends intend to visit: Tom promises such sights as women who hire children so they can pose as distressed mothers, cripples who abandon their crutches to 'join in a reel', and a 'HYPOCRITE' who sings hymns in the streets and swears 'horrid imprecations' in the tavern. ${ }^{95}$ According to Tom, 'a volume would not contain one-half of the impositions that are daily practised upon the public by the beggars of the Metropolis' and they are about to enter an 'assemblage of rascality, wickedness, and deceit' ${ }^{96}$ These beggars, we are assured, earn 'much better living than thousands of hard-working journeymen in the Metropolis,,${ }^{97}$ and get great enjoyment from fooling the 'flats' who give them charity. This serves to insulate the reader from any sense of social responsibility for the poor: their lives are one long street performance of deserving poverty, but in their 'Beggars' Opera' they are presented as both actors and their own appreciative audience, as they all '[join] in the laugh, among the begging fraternity, at the credulity of mankind' ${ }^{98}$ The Cadgers recognise Tom and his companions as fellow performers, as they soon see through their 'outward appearance of Beggars' .99 Yet on another level, it is these very performances which make them one of the sights of London that Tom feels Jerry absolutely must see, in order to return to Hawthorn Hall having experienced authentic London life. Like the Green Room at Drury Lane theatre, the Holy Land is where the costumes come off and the performance is revealed; '[q]uarrelsome old Suke, who has been hobbling all day on her crutches through the streets, now descends the ladder quickly to join the party'. ${ }^{100}$ But this unmasking only serves to prove the authenticity of their knowingness, and of their status as 'such a portraiture of the versatility of human nature'. ${ }^{101}$ 
This kind of authenticity can only be tested by sight, not by talk, as the visual image of 'portraiture' suggests. It is not just Waters's image that is offered as a 'real' portrait here: Charles McGee and Andrew Whiston, both well-known figures on the London streets, also appear very clearly in the bottom right of the plate. ${ }^{102}$ Logic instructs Jerry to 'Observe and be silent', ${ }^{103}$ but that this is an observation of artistic appreciation rather than judgemental surveillance is made clear by the visual language of Egan's letterpress. The 'extraordinary scene' is 'a rich view of Human Nature'; 104 indeed the word 'scene' is repeated again and again as if the plates are theatre scenes, and Egan is supplying the sound to the visuals. Egan declares that:

we shall pass from ALL-MAX in the East to ALMACKS in the West almost like the rapid succession of scenes in a play, which will tend highly to increase the effect, and likewise afford a good opportunity for observation. ${ }^{105}$

Observing the spectacle of the city is a vital stage in knowing it for what it is. As Jerry puts it, 'I have heard talk of the varieties of "LIFE IN LONDON", but what I have already seen beggars description', with one of Egan's characteristic puns on the word 'beggar'. ${ }^{106}$ Moncrieff takes these materials and gives 'Billy Waters' a speaking role. However, the resulting emphasis on Billy's theatricality denies him individuality even as it seems to celebrate it and distracts from social realities. On the one hand, the Cadgers are given identities, personalities, and the freedom to have fun. On the other, they are depicted as cheats and frauds. Poverty and social exclusion brought about through the social constructions of class, race, and disability are turned into an enjoyable romp. It is the real marginalised Londoners such as Waters who suffer the consequences. Jennifer Wicke has argued that the late nineteenth-century saw a cultural unease emerge over the replication, multiplication, and proliferation of texts and forms, as new technologies such as the typewriter enabled faster and easier copying. ${ }^{107}$ Moncrieff's exuberant Cadgers scene 
registers none of this unease. If a performance can trick people with its presumed authenticity then so much the better, Moncrieff's play suggests; if stage scenes can contribute to the growing Life in London craze and this brings profit, great. But this carefree attitude produces an uncomfortable tension between the commodification of authenticity and the ethical imperative of authentically conveying the experience of the marginalised.

Visualising the pan-media operations of Regency popular culture as a communication network allows us to see how the network of illustrations of Billy Waters on stage and page complicated distinctions between 'real' citizens with bodies, the bodies of 'real' citizens as depicted on the page, actors with bodies, fictional characters on the stage embodied by the actors, and fictional characters on the page whose bodies can only be conjured up with words. There is more work to be done on what this means for nineteenth-century theatre and other media, for the study of black British history (in the academy and in schools), and for authorship and reception studies. Future work might also consider the implications of the fascination of Dickens's earliest illustrator with an impoverished black Londoner, and the significance of the association of 1820s London spectacle with a performer who is non-white and with a disability. This model of the communication network also allows us to approach the circulation of popular characters such as Mr Pickwick from a new perspective. Instead of classifying the explosion of Pickwickiana with terms which carry either a pejorative undertone (plagiarisms, imitations) or a modern framework (fanfiction), we can recast the outpourings of plays, texts, images, and material objects associated with this and other nineteenth-century cultural crazes as part of the communication network of popular culture. ${ }^{108}$ Thinking in terms of a communication network offers us not only a deeper understanding of how this dangerous theatricality left Billy Waters' historical body disregarded and impoverished, but also a new way of conceptualising how tropes and stereotypes circulate horizontally across the matrix of vernacular culture. 
Mary L. Shannon, University of Roehampton, London, UK

Notes

I am grateful to Rachele Dinai, Ian Haywood, Andy Kesson, Katherine Newey, Brian

Maidment, Susan Matthews, and Rohan McWilliam for their comments on earlier versions of this article.

${ }^{1}$ Waters is discussed briefly in Brian Maidment, Dusty Bob: A Cultural History of Dustmen, 1780-1870 (Manchester: Manchester UP, 2007), and Charles Hindley, The True History of Tom and Jerry (London: Charles Hindley, n.d. [1892]). His transatlantic resonances are discussed in Jenna M. Gibbs, Performing the Temple of Liberty: Slavery, Theatre, and Popular Culture in London and Philadelphia, 1760-1850 (Johns Hopkins UP: Baltimore, 2014). He is also mentioned in Peter P. Reed, Rogue Performances: Staging the Underclasses in Early American Theatre Culture (Palgrave Macmillan: NY, 2009). The prints and texts which immortalised him are fleetingly referenced as part of black British history collections at the Victoria and Albert Museum, the National Portrait Gallery, and the National Maritime Museum. But nowhere does he get any sustained treatment, and information is inaccurate in some sources.

${ }^{2}$ Billy Waters may or may not have at one point been a slave: see the rather fanciful 'biographical sketch' in Hindley, True History, p. 103, attributed to W.T. Moncrieff.

${ }^{3}$ As Reid puts it, 'To say that Life in London was a phenomenal success is not to exaggerate' (J. C. Reid, Bucks and Bruisers: Pierce Egan and Regency England (London: Routledge \& Kegan Paul, 1971), p. 73.).

${ }^{4}$ James G. Hepburn, A Book of Scattered Leaves: Poetry of Poverty in Broadside Ballads, 2 vols. (Lewisburg, PA: Bucknell UP, 2000 - 2001), 1: 33; 2: 308-311.

${ }^{5}$ W.T. Moncrieff, 'Tom and Jerry; Or, Life in London', in Cumberland's British Theatre, vol. 33 ( London: John Cumberland, [n.d.]), p. 8. 
${ }^{6}$ Charles Hindley, The Life and Times of James Catnach (Late of Seven Dials), Balladmonger (London: Charles Hindley, 1878), p. 135.

${ }^{7}$ James Catnach, The Death, Last Will, and Funeral of Black Billy; also the Tears of London for the Death of Tom and Jerry (London: Catnach, c.1823); Douglas Jerrold, 'The Ballad Singer', in The Writings of Douglas Jerrold, vol. 5 (London: 1851-4), p. 225. For black dance in nineteenth-century London, see Rodreguez KingDorset, Black Dance in London, 1730-1850: Innovation, Tradition, and Resistance, (Jefferson, NC: McFarland \& Company, Inc., 2008).

${ }^{8}$ Hindley, True History, 10.

${ }^{9}$ On Pickwick see Adam Abraham, ‘Plagiarizing Pickwick: Imitations of Immortality', Dickens Quarterly, 32:1 (2015), 5-20; on Paul Pry see David Vincent, I Hope I Don't Intrude? Privacy and its Dilemmas in NineteenthCentury Britain (Oxford: OUP, 2015); on Life in London characters see Brian Maidment, Dusty Bob, and Reid, Bucks and Bruisers.

${ }^{10}$ Dusty Bob and African Sal were carnivalesque figures who, like Billy, were given a much more extended role in Moncrieff's play than in the book. However, they appear in different scenes in the play, and different plates in the book. One 1822 print depicts them in the same tavern, but only because it is 'an unfocused gathering of Life in London tropes' (Maidment, Dusty Bob, p.75) - although the cataloguer has not spotted that the fiddler is in fact Billy Waters (http://findit.library.yale.edu/catalog/digcoll:974919, accessed 14.01.19).

${ }^{11}$ See, for example, the special issue of this journal on theatre, art, and visual culture edited by Patricia Smyth (Nineteenth Century Theatre \& Film, 39:1 (2012).

${ }^{12}$ Information on the details of his life differed even during the nineteenth-century: Chamber's Edinburgh Journal contradicts Hindley and other printed accounts by declaring that 'one Billy Waters, of cocked-hat and wooden-leg memory, died, it was said, a man of substance.' In support of Hindley see a newspaper cutting in the V \& A collections <http://collections.vam.ac.uk/item/O70019/scrapbook-unknown/>, accessed 04.12.18. But the physical existence of Billy Waters, including the details of his act, is not a matter of dispute.

${ }^{13}$ Pierce Egan, illus. Robert and George Cruikshank, Life in London (London: Sherwood, Neely and Jones, 1822), p. 178.

${ }^{14} \mathrm{Jim}$ Davis, Comic Acting and Portraiture in Late-Georgian and Regency England (Cambridge: CUP, 2015).

${ }^{15}$ Katherine Newey, 'Attic Windows and Street Scenes: Victorian Images of the City on the Stage', Victorian Literature and Culture, 25:2 (1997), 253-62, 260. 
${ }^{16}$ Hindley, Life and Times, p. 135; W. Reeves, 'Lines on Billy Waters' (June 1823), reproduced in Hindley, True History, p. 108. Although Catnach's ballad claims in fact 'That Tom and Jerry's sudden death,/ Has poor Black Billy kill'd outright!' (Catnach, Death).

${ }^{17}$ Of course, the example of John Liston as Paul Pry shows that in many cases fame involves losing ownership of your image. However, Liston the successful actor is able to purchase items with his own face on them, and plays his own character live on stage instead of seeing it performed for him (Vincent, I Hope I Don't Intrude?, pp. 76-9). Later in the century, The Crippled Street-seller of Nutmeg-graters featured in Henry Mayhew's (illustrated) London Labour and the London Poor writes to Mayhew that he is grateful for the funds he has received but as a result of being in Mayhew's publication he is 'gazed at in the street with astonishment; and observations made in my hearing with respect to the Exact Likeness of the portrait'; he has become a local 'show' whom strangers view as a spectacle rather than with true sympathy (Bernard Taithe, ed., The Essential Mayhew: Representing and Communicating the Poor (London: Rivers Oram Press, 1996), p. 134).

${ }^{18}$ Gareth Stedman Jones, An End to Poverty? A Historical Debate (London: Profile Books, 2004), p. 13.

${ }^{19}$ Robert Darnton, 'What is the History of Books?', Daedalus (Summer 1982), 65-83.

${ }^{20} \mathrm{Ibid} ., 66$.

${ }^{21}$ Ibid., 67.

${ }^{22}$ Thomas R. Adams and Nicolas Barker, 'A New Model of the Study of the Book', in David Finkelstein and Alastair McCleery (eds), The Book History Reader (London: Routledge, 2006), pp. 47-65.

${ }^{23}$ Innes M. Keighren, 'Bringing Geography to the Book: Charting the Reception of Influences of Geographic Environment', Transactions of the Institute of British Geographers, 31:4 (2006), 525-40; James Secord, Victorian Sensation: The Extraordinary Publication, Reception, and Secret Authorship of Vestiges of the Natural History of Creation (Chicago: U of Chicago P, 2000); The Grub Street Project <http://grubstreetproject.net/distributednetwork.php〉, accessed 04.12.18.

${ }^{24}$ Robert Darnton, 'An Early information Society: News and Media in Eighteenth-Century Paris', The American Historical Review, 105:1 (2000), 1-35, 7-8.

${ }^{25}$ Darnton, 'What is the History of Books?', 80.

${ }^{26}$ Ibid., 69.

${ }^{27}$ Leigh Dilliard, "Drawing Outside the Book: Parallel Illustration and the Creation of a Visual Culture" in Christina Ionescu (ed.) Book Illustration in the Long Eighteenth Century: reconfiguring the Visual Periphery of the Text (Newcastle: Cambridge Scholars Publishing, 2011), pp. 915 - 241, p. 195. 
${ }^{28}$ Dilliard, 'Drawing Outside the Book', p. 196. Ian Haywood uses the term 'ancillary illustrations' for this (Ian Haywood, 'A metropolis in flames and a nation in ruins: the Gordon Riots as sublime spectacle', in Ian Haywood and John Seed (eds), The Gordon Riots: Politics, Culture, and Insurrection in Late EighteenthCentury Britain (Cambridge: CUP, 2012), p. 122.

${ }^{29}$ Ian Haywood, Susan Matthews, and Mary L. Shannon, 'Introduction', in Ian Haywood, Susan Matthews, and Mary L. Shannon, (eds ), Romanticism and Illustration (Cambridge: CUP, forthcoming, 2019).

${ }^{30}$ Martin Meisel, Realizations: Narrative, Pictorial and Theatrical Arts in Nineteenth-Century England (Princeton, NJ: Princeton UP, 1983).

${ }^{31}$ Patricia Smyth, 'Editorial: Theatre, Art, and Visual Culture in the Nineteenth Century', Nineteenth Century Theatre \& Film, 39:1 (2012), xvii-xxv.

${ }^{32}$ On plagiarism and alternative terms, see Abraham, 'Plagiarizing Pickwick'.

${ }^{33}$ Tracy C. Davis and Thomas Postlewait, 'Theatricality: an Introduction', in Davis and Postlewait (eds), Theatricality (Cambridge: CUP, 2003) pp. 1-39, pp. 1-2; p. 4.

${ }^{34}$ Tracy C. Davis, 'Theatricality and Civil Society', in Theatricality, pp. 127-55, p. 128.

${ }^{35}$ Ibid., pp. 145-6. Here Davis is drawing upon Michael Fried, Absorption and Theatricality: Painting and Beholder in the Age of Diderot (California: U of California P, 1980).

${ }^{36}$ Tom Scriven, 'The Jim Crow Craze in London's Press and Streets, 1836-9', Journal of Victorian Culture, 19:1 (2014), 93-109, 102.

${ }^{37}$ This was common in the period: see Richard D. Altick, The Shows of London (Cambridge, MA: Harvard UP, 1978).

${ }^{38}$ On this idea in relation to 'Boz' and his illustrator George Cruikshank, see Mary L. Shannon, 'Dickens in Byron's Chair: Authenticity, Author Portraits, and Nineteenth-Century Visual Culture', Victorian Literature and Culture 46:1 (2018), 57 - 81 .

${ }^{39}$ See the digitised copy at https://digitalcollections.nypl.org/items/510d47dc-99cf-a3d9-e040e00a18064a99/book?parent=6a5f6f30-c6bb-012f-e577-58d385a7bc34\#page/3/mode/2up. Accessed 10.01.19.

${ }^{40}$ I am grateful to Andy Kesson for drawing this to my attention.

${ }^{41}$ Kirsten Olsen, Daily Life in 18th Century England (Westport: Greenwood, 1999), p. 29.

${ }^{42}$ Gretchen Holbrook Gerzina, 'Introduction', in Grezina (ed.), Black Victorians/Black Victoriana (New Brunswick: Rutgers UP, 2003), pp. 1-9, p.4.

${ }^{43}$ Shannon, 'Dickens in Byron's Chair', 59. 
44 "authenticity, n.". OED Online. December 2014. OUP. 18 July 2016.

${ }^{45}$ Marcus Wood, Slavery, Empathy, and Pornography (Oxford: OUP, 2002), p. 16.

${ }^{46}$ For more on the grotesque mode of depicting black people in the nineteenth-century, see Hazel Waters, Racism on the Victorian Stage (Cambridge: CUP, 2007).

${ }^{47}$ I am grateful to Susan Matthews for pointing this out.

${ }^{48}$ See online at https://www.britishmuseum.org/research/collection_online/collection_object_details.aspx?objectId=1478376\&p $\operatorname{artId}=1 \&$ searchText=landing+the+treasures+cruikshank\&people=92620\&page=1. Accessed 10.01.19.

49 'Arriving in London, he betook himself to that wild mode of life, which best suited his origin; the trammels of civilized society, had no charm for him; he scorned the mechanical rules of man, and picked up his living wherever he could find it. Born a Prince, and bearing a native princeliness in his appearance it is not to be wondered at that his associates should speedly elect him to the regal dignity of their tribe.' (Hindley, True History, p. 103).

${ }^{50}$ Reid, Bucks and Bruisers, p. 73.

${ }^{51}$ Egan, Life in London, p. 347.

52 'Holy Land' was the nickname for St. Giles because of its large population of Irish Catholics.

${ }^{53}$ Egan, Life in London, p. 346.

${ }^{54}$ Hepburn, Scattered Leaves, 1: 33.

${ }^{55}$ Billy reappears in George Smeeton's imitation of Life in London, Doings in London; or, Day and Night Scenes of the frauds, frolics, manners and depravities of the Metropolis (London: Orlando Hodgson, 1828), in an illustration designed by Robert Cruikshank (p. 114). I am grateful to Ian Haywood for bringing this to my attention.

${ }^{56}$ Pierce Egan, The Finish to the Adventures of Tom, Jerry, and Logic, in their pursuits through Life In and Out of London. By Pierce Egan. With Numerous Illustrations by Robert Cruikshank (London: Reeves \& Turner, 1869), p. 10.

${ }^{57}$ From the late eighteenth-century, many military bands included black drummers and other musicians; one illustration to Life in London shows such musicians entertaining a crowd (Stella Beddoe, A Potted History: Henry Willett's Ceramic Chronicle of Britain (Woodbridge: ACC Art Books Ltd, 2015), p. 183).

${ }^{58}$ Beddoe, A Potted History, p. 182. 
${ }^{59}$ See https://bathartandarchitecture.blogspot.com/2017/05/billy-waters-by-robert-shout.html, accessed 10.01.19. I have tried to track down the original of this image, but to no avail.

${ }^{60}$ Thomas, Busby, Cries of London Drawn from Life (1823); [William Hodgson], The Cries of London (London: Hodgson \& Co, c. 1824). Hindley's True History also contains multiple images of Billy.

${ }^{61}$ Maidment, Dusty Bob, p. 60; Gibbs, Performing the Temple of Liberty, p. 129. For Moncrieff's career adapting fiction into plays see Philip Cox, Reading Adaptations: Novels and Verse Narratives on the Stage, 1790-1840. Manchester: MUP, 2000), pp. 126-62.

${ }^{62}$ Maidment, Dusty Bob, p. 63; p. 61.

${ }^{63}$ Hindley, True History p. 86-7. Maidment counts 'at least six different versions, to say nothing of minor variations and new productions of [Moncrieff's version]' (59).

${ }^{64}$ Hindley, True History, p. 92-3 and Catnach, p. 120; Gibbs, Performing the Temple of Liberty, p. 131; Reed, Rogue Performances, pp. 129-130.

${ }^{65}$ Maidment, Dusty Bob, p. 59. As Reed points out, audiences in America were 'less likely to have confused Waters for a real street performer, given his London origins'. (Rogue Performances, p.130).

${ }^{66}$ Hindley, Catnach, p. 113 ; Hindley, True History, p. 8; D[aniels], G[eorge], 'Remarks', from Charles Hindley, True History, pp. 5-7, p. 5.

${ }^{67}$ quoted in William Clarke, Every Night Book or Life After Dark (London: T. Richardson, 1827), p. 801.

${ }^{68}$ Victoria and Albert Museum Theatre Archives. Adelphi 1820 - 1825, Adelphi 1821. Playbill. Tom and Jerry. December 1821.

${ }^{69}$ Cox, Reading Adaptations, p. 143.

${ }^{70}$ See Shannon, 'Dickens in Byron's Chair', on this strategy in relation to 'Boz' and to the characters Tom and Jerry.

${ }^{71}$ W.T. Moncrieff, ‘Tom and Jerry; Or, Life in London', Cumberland's British Theatre, vol. 33 (London: John Cumberland, [n.d.]), p. 8.

${ }^{72}$ Ibid., p. 47.

${ }^{73}$ Moncrieff, 'Tom and Jerry', p. 47. This draws upon a tradition of Characters in comic writing dating from Theophrastus' influential sketches of various types of individuals to be met with on the streets of ancient Athens. See James Diggle (ed.), Theophrastus: Characters (Cambridge: Cambridge UP, 2003). 
${ }^{74}$ See D[aniels], 'Remarks', pp. 5-7, and Reed, p. 130; Hindley declares that Billy Waters 'possessed abilities/ that as an actor would have rendered him a shining ornament to the stage' (True History, pp. 106-7). Critics continue to be confused to this day.

${ }^{75}$ Moncrieff, 'Tom and Jerry', p. 47.

${ }^{76}$ I am grateful to Susan Matthews for this point.

${ }^{77}$ Hepburn, Scattered Leaves, 2: 301.

${ }^{78}$ Parliamentary Papers, Reports from the Select Committee on the State of Mendicity in the Metropolis, vol. 5 (1816), pp. $391-416$.

${ }^{79}$ Hepburn, Scattered Leaves, 2:300.

${ }^{80}$ Moncrieff, ‘Tom and Jerry’, p. 49.

${ }^{81}$ Ibid., p. 50.

${ }^{82}$ See, for example, Cesar the black footman in Douglas Jerrold, The History of St. Giles and St. James (London: Bradbury and Evans, 1851).

${ }^{83}$ Moncrieff, 'Tom and Jerry', pp. 49-50. Egan's Billy was more of an onlooker (Gibbs, Performing the Temple of Liberty, p.).

${ }^{84}$ Hindley, True History, p. 105.

${ }^{85}$ Gibbs, Performing the Temple of Liberty, p. 128.

${ }^{86}$ Heidi J. Holder, 'Other Londoners: Race and Class in Plays of Nineteenth-Century London Life', in Pamela Gilbert (ed.), Imagined Londons (Albany: State University of New York P, 2002), pp. 31- 44, p. 34.

${ }^{87}$ Hazel Waters, Racism on the Victorian Stage (Cambridge: CUP, 2007), p. 2.

${ }^{88}$ W. Reeves, 'Lines on Billy Waters' June 1823, reproduced in Hindley, True History, p. 108.

${ }^{89}$ Hindley, Life and Times, p. 135.

${ }^{90}$ Egan, Finish, pp.7-9.

${ }^{91}$ Victoria and Albert Museum Theatre Archives. Playbill.

${ }^{92}$ See Shannon, 'Dickens in Byron's Chair'. For an interesting discussion of questions of the adequacy of representation in Life in London, see David Brewer, 'The Moment of Tom and Jerry: "When fisticuffs were in fashion"', Romantic Praxis, http://dev.rc.umd.edu/praxis/fandom/praxis.fandom.2010.brewer.html, accessed 04.12.18.

${ }^{93}$ Moncrieff, ‘Tom and Jerry', p. 346. 
${ }^{94}$ Ibid., p. 342. Masquerading is a key motif throughout the text: see Gregory Dart, Metropolitan Art and

Literature, 1810-1840: Cockney Adventures (Cambridge: CUP, 2015).

${ }^{95}$ Moncrieff, 'Tom and Jerry', p. 343; p. 344.

${ }^{96}$ Ibid., p. 345.

${ }^{97}$ Ibid.

${ }^{98}$ Ibid

${ }^{99}$ Ibid., p. 342.

${ }^{100}$ Ibid., p. 346.

${ }^{101}$ Ibid., p. 347.

${ }^{102}$ Peter Fryer, Staying Power: The History of Black People in Britain. London: Pluto Press, 1984), p. 231.

${ }^{103}$ Moncrieff, 'Tom and Jerry', p. 346.

${ }^{104}$ Ibid., p. 342; p. 343.

${ }^{105}$ Ibid., p. 291.

${ }^{106}$ Ibid., p. 227.

${ }^{107}$ Jennifer Wicke, 'Vampiric Typewriting: Dracula and its Media', ELH, 59:2 (1992), 467-93.

${ }^{108}$ See Abrams, 'Plagiarizing Pickwick'. For a discussion of the role of images in Pickwick imitations, see also Ian Haywood, 'The Importance of 'Phis': The Role of Illustration in Lloyd's Imitations of Dickens', in Sarah Louise Lill and Rohan McWilliam (eds), Edward Lloyd and His World: Popular Fiction, Politics and the Press in Victorian Britain (Abingdon: Routledge, 2019), pp. 71-95. (forthcoming). 